\title{
Effects of Acetyl Glutamine on the Improvement of Skin Barrier and Inhibition of Senescence
}

\author{
Hyun Hee Jang \\ School of Cosmetology, Kyungbok University, Namyangju-si, Gyeonggi-do, Korea
}

Corresponding author: Hyun Hee Jang, School of Cosmetology, Kyungbok University, 425 Kyungbokdae-ro, Jinjeopeup, Namyangju-si, Gyeonggi-do 12051, Korea

Tel.: +82 315709741

Fax: +82 315709748

Email: kjjang@kbu.ac.kr

Received October 29, 2018

Revised November 07, 2018

Accepted November 08, 2018

Published December 30, 2018

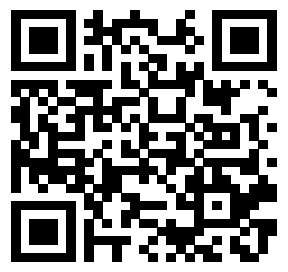

\begin{abstract}
Purpose: The purpose of this work is to investigate the effects of acetyl glutamine (NAG) as a cosmetic ingredient-the effect of the inhibition of senescence and enhancing skin barrier-through cell-based assays. Methods: We confirmed the effects of NAG using cell viability, SA- $\beta$-galactosidase assay, western blotting and quantitative real-time PCR. Results: NAG did not affect cell viability. NAG at $20 \mathrm{mM}$ showed a significant protective effect against $\mathrm{H}_{2} \mathrm{O}_{2}$-induced loss of cell viability at 100, $200 \mu \mathrm{M}$. It was found that $20 \mathrm{mM}$ NAG reduced senescence cells in $\mathrm{H}_{2} \mathrm{O}_{2}$ induced HaCaT far more than glutamine (GIn) in SA- $\beta$-gal positive cells. NAG at $20 \mathrm{mM}$ increased expressions of keratin 1 and involucrin remarkably more than GIn. It indicates that NAG has better efficacy in facilitating differentiation of epidermal keratinocyte than GIn. Also, NAG reduced nuclear accumulation of p53, a homotetrameric transcription factor, and expression of p21 in HDFs with $\mathrm{H}_{2} \mathrm{O}_{2}$. NAG decreases expression levels of matrix metallopeptidase 1 (MMP1) mRNA in HDFs with $\mathrm{H}_{2} \mathrm{O}_{2}$. The $\mathrm{H}_{2} \mathrm{O}_{2}$-induced decrease in the levels of collagen, type I, alpha 1 (COL1A1) expression were significantly increased by treatment with NAG. The result indicates that NAG effectively controls senescence cells triggered by $\mathrm{H}_{2} \mathrm{O}_{2}$. As a result, it was found that NAG was effective in maintaining moisture of stratum corneum, the most important function of skin barrier. Conclusion: As shown earlier, this work tested NAG's effects of the inhibition of senescence and enhancing skin barrier. These findings suggest that NAG might be used as a cosmetic ingredient.
\end{abstract}

Keywords: Acetyl glutamine, Skin barrier, Senescence, HaCaT, HDFs

\section{Introduction}

피부는 인체에서 가장 큰 기관이며 신체의 표면을 덮고 있는 조 직으로 크게 표피와 진피로 구분된다. 또한 외부환경에 대한 보 호 장벽으로서 몸을 보호하는 역할을 하며(Kim et al., 2009), 면 역반응을 나타내는 대표적인 장기이다(Jeong et al., 2012). 그 중 표피는 매우 복잡하고 역동적이며 자기재생적인 피부장벽으로 (Seo, 2012), 세포의 형성, 분화 및 탈각과정이 끊임없이 반복되 면서 표피의 항상성을 유지한다(Park, 2007). 표피의 주요 구성 세포는 각질형성세포로 분화 정도에 따라 기저층, 유극층, 과립 층, 각질층의 4 개 층으로 나뉜다. 피부장벽은 표피층의 분화과정 을 통해 형성되며, 표피의 가장 윗 층인 각질층은 피부장벽 기능 중 가장 중요한 수분손실 방지와 외부 유해물질의 침입을 막는 방
어막 역할을 한다(Kwon et al., 2007).

표피에서의 세포확산은 기저층의 표피 줄기세포에서 이루어진 다(Seo, 2012). 각질형성세포의 분화과정(differentiation)은 정 교하게 조절 받는 유전자발현 변화의 결과로서 분화 단계별 표 지 유전자(marker gene)들의 발현 조절 연구는 표피 분화과정 의 기작을 밝히는데 중요한 역할을 한다. 기저층에서는 keratin 5 와 14 가 발현되는데 분화과정으로 이행하면 발현이 중단된다 (quoted in Kim et al, 2004). 기저층 위에서는 keratin 1 과 10 을 유극층 및 과립층에서는 각질세포막 연관 단백질인 involucrin, loricrin, envoplakin 등이 합성된다(Park, 2007; Choi \& Oh, 2008). 각질세포막은 분화과정의 마지막 단계에서 형성되는데 각질 세포 단백질외막내의 involucrin 복합체는 각질 단백막을 둘러싸는 지질막을 형성한다(Kim et al., 2013b). 
피부 보습에 중요한 각질층의 수분함량이 저하되면 건조증상과 피부장벽 기능의 이상이 나타나는데, 보습제는 각질층내의 수분 유 지와 대사 작용이 원활하게 이루어지도록 도와주는 역할을 한다 (Chang et al., 2007). 최근 피부 보습제는 그 유효성이 건조증상의 호전에서부터 피부노화의 개선에 이르기까지 다양하다. 또한 장기 간의 보습제 도포가 피부장벽 기능을 향상시키고 중지한 후에도 정 상적인 피부장벽 기능을 방해(down regulation)하지 않는다(Lee et al., 2011)는 보고가 있다.

건강한 피부 상태의 유지를 위해서 각질층은 약 $30 \%$ 정도의 수 분을 함유해야 하며, 아미노산은 피부의 보습상태에 중요한 역할을 한다는 연구가 다수 보고되었다(Kim et al., 2013a). NMF의 주성 분인 아미노산의 함량은 보습과 관련한 각질의 생리기능과 밀접한 관련이 있고, 아미노산의 함량이 높을수록 보습유지에 효과적이라 는 보고가 있다(Joo et al., 2012). 이와 같이 아미노산은 대표적인 보습성분으로서 피부각질층의 수분보유 능력에 중요한 $\mathrm{NMF}$ 중 약 $40 \%$ 를 차지하는데(Park et al., 2003) 글루타민(L-glutamine)은 $\mathrm{NMF}$ 의 중요한 아미노산 성분 중 하나이다.

글루타민(L-glutamine, Gln)은 체내에 가장 많이 존재하는 조건 적 필수 아미노산으로 단백질 합성과 세포내 에너지원으로 활용된 다. 글루타민은 심각한 질병상태에서 농도가 감소되기 때문에 치료 시 필수적이며(Agostini \& Biolo, 2010), 세포증식, 유전자 발현조 절(Brasse-Lagnel et al., 2009), 단백질 합성(Newsholme et al., 2003), 항염증 작용(Zhang et al., 2008), 면역기능 조절(Singleton et al., 2005), 항산화 작용(Wischmeyer, 2008), 뇌세포 에너지원 (Choi et al., 2005), 알레르기성 접촉성 피부염 억제와 전신적인 과 민성 알레르기 질환인 후기 아나필락시스 억제 등의 효과가 보고되 어져 있다.

아세틸글루타민(N-Acetyl L-glutamine)은 글루타민의 amine 기에 acetyl 기가 결합 된 것으로 글루타민에 비해 화학적 안정성이 높고, 특히 물에서 더 안정적으로 존재하고 세포 내에서 글루타민 과 거의 유사한 대사과정을 거치면서, 글루타민에 비하여 세포에 처 리 시 초기에 안정적인 물질로 활용된다(Yoon et al., 2013; Yoon, 2013).

본 연구에서는 산화적 스트레스가 유도된 인간 피부세포에서 아 세틸글루타민의 세포노화 억제 및 각질형성세포 분화조절 효과를 세포효력시험을 통해 검증함으로써 아세틸글루타민의 항노화 및 피 부장벽 기능 강화 화장품 원료로서의 응용가능성을 제시하고자 한 다.

\section{Methods}

\section{1. 세포배양 및 시료처리}

본 연구에서는 인간 각질형성세포주( $\mathrm{HaCaT} ; \mathrm{ATCC}, \mathrm{USA})$ 와
인간 진피섬유아세포(human dermal fibroblasts, HDFs; Lonza, USA)를 사용하였다. HaCaT, HDFs의 배양에는 $10 \%$ fetal bovine serum (FBS)과 $1 \%$ penicillin/streptomycin이 첨가된 DMEM 배지 (Welgene, Korea)를 사용하였으며 $37^{\circ} \mathrm{C}, 5 \% \mathrm{CO}_{2}$ 조건에서 배양하였 다. 세포 실험에서 사용된 glutamine (Gln)과 N-Acetyl glutamine (NAG; Sigma, USA)은 DMSO에 녹여 사용하였다. Cell culture dish에 HaCaT과 HDFs $\left(1 \times 10^{6}\right)$ 를 $24 \mathrm{~h}$ 배양한 후 Gln, NAG를 배 지에 첨가하여 $2 \mathrm{~h}$ 동안 전 처리하였다. 전처리 후 배지를 제거하고 phosphate-buffered saline (PBS)로 2회 세척한 뒤, 배지에 혼합된 $\mathrm{Gln}, \mathrm{NAG}$ 과 $\mathrm{H}_{2} \mathrm{O}_{2}$ 를 $2 \mathrm{~h}$ 동안 처리한 후 PBS로 세척하였다. 그 후 $\mathrm{Gln}, \mathrm{NAG}$ 만 새로운 배지에 첨가하여 $24 \mathrm{~h}$ 배양하고 실험을 실시하 였다.

\section{2. 세포 생존율}

Cell viability 측정 실험에는 WST-1 assay 원리를 이용한 EZCytox cell viability assay kit (이츠바이오, Korea)를 사용하였다. $\mathrm{HaCaT}, \mathrm{HDFs}\left(3 \times 10^{3}\right)$ 를 96-well plate에 배양하고, $24 \mathrm{~h}$ 후 well 당 Gln, NAG과 $\mathrm{H}_{2} \mathrm{O}_{2}$ 를 각각 $0.002,0.02,0.2,2,20,200 \mathrm{mM}$ 과 $60,80,100,200,400,600,800 \mu \mathrm{M}$ 의 농도로 처리하여 $24 \mathrm{~h}$ 배양 하였다. 배양된 세포에 kit reagent를 $10 \mu \mathrm{L}$ 첨가하여 $1 \mathrm{~h}$ 배양 후 microplate reader (Bio-Rad, USA)를 이용하여 $490 \mathrm{~nm}$ 의 파장에서 흡광도를 측정하였다. Cell viability 측정은 3 회 반복으로 실시하였으 며, 수행한 실험 결과에서 대조군과 실험군을 비교하여 나타내었다.

\section{3. 세포 노화 측정}

Senescence detection kit (Biovision, USA)를 사용하였으며, 세 포 노화 측정의 바이오마커인 $\beta$-galactosidase의 활성 측정법인 SA- $\beta$-galactosidase assay를 이용하였다. HaCaT $\left(1 \times 10^{6}\right)$ 을 60 $\mathrm{mm}$ culture dish에 접종하여 $24 \mathrm{~h}$ 동안 배양하여 안정화 시킨 후 $\mathrm{Gln}, \mathrm{NAG} 20 \mathrm{mM}$ 을 각각 전처리하고, $\mathrm{H}_{2} \mathrm{O}_{2} 100 \mu \mathrm{M}$ 를 처리한 후 다시 $24 \mathrm{~h}$ 배양하였다. 배양된 세포는 배지 제거 후 $1 \mathrm{~mL} \mathrm{PBS로} 1$ 회 세척하고, $0.5 \mathrm{~mL}$ fixing solution을 첨가 후 상온에서 $15 \mathrm{~min}$ 방치하여 고정화 하였다. 고정된 세포는 $1 \mathrm{~mL} \mathrm{PBS로} 2$ 번 세척 한 후 staining solution mix (staining solution $470 \mu \mathrm{L}$, staining supplement $5 \mu \mathrm{L}, 20 \mathrm{mg} / \mathrm{mL} \mathrm{X}-\mathrm{Gal}$ in dimethylformamide 25 $\mu \mathrm{L})$ 를 $0.5 \mathrm{~mL}$ 씩 첨가하고 $37^{\circ} \mathrm{C}$ 에서 $24 \mathrm{~h}$ 동안 배양하여 염색하였 다. 염색된 세포는 $1 \mathrm{~mL} \mathrm{PBS로} \mathrm{세척} \mathrm{후} 1 \mathrm{~mL} 70 \%$ glycerol을 넣고 광학현미경(Olympus, Japan)을 통하여 세포 수를 측정하였다. 세포 의 노화 정도는 전체 세포 수와 염색된 세포 수를 비교하여 노화된 세 포(senescent cell)의 비율을 퍼센트로 나타내어 확인하였다.

\section{Western blotting}

$\mathrm{Gln}, \mathrm{NAG}$ 과 $\mathrm{H}_{2} \mathrm{O}_{2}$ 를 적정 농도로 처리 후 $24 \mathrm{~h}$ 배양한 $\mathrm{HaCaT}$ 을 수확하여 PBS로 세척 후 RIPA buffer $(50 \mathrm{mM}$ Tris- $\mathrm{Cl}(\mathrm{pH}$ 

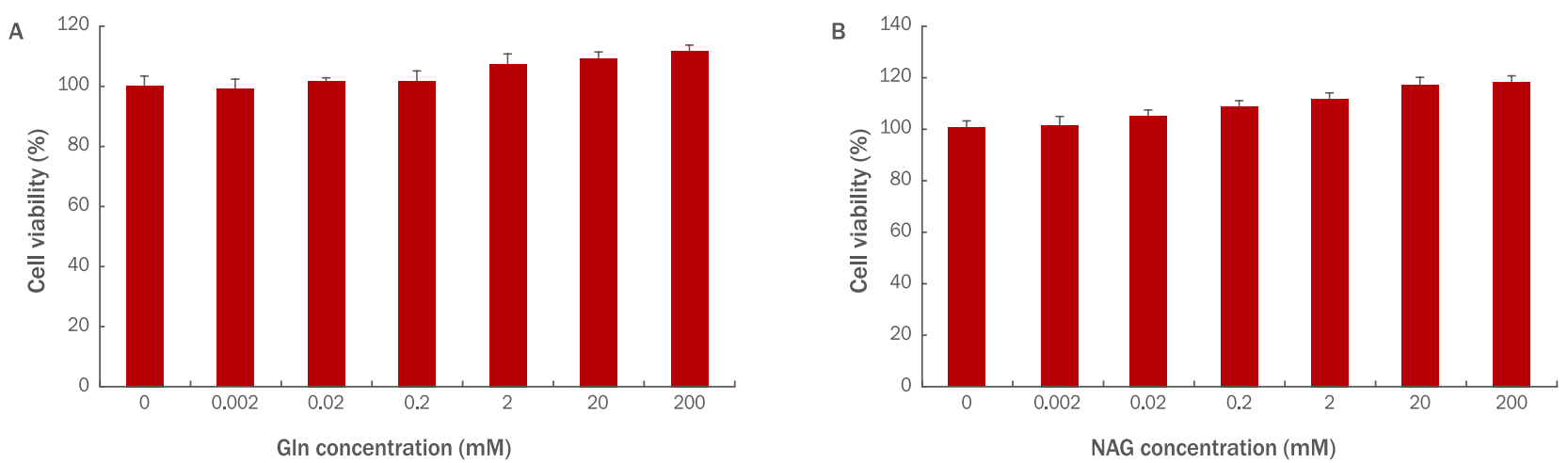

Figure 1. Cytotoxicity of Gln (A) and NAG (B) on HaCaT.

Cell viability of GIn and NAG on HaCaT $\left(3 \times 10^{3}\right)$ was measured by the WST-1 assay. (A) Gln was non-toxic to HaCaT at the $0.002,0.02,0.2$, 2, 20, and $200 \mathrm{mM}$ concentrations. (B) NAG was non-toxic to HaCaT at the 0.002, 0.02, 0.2, 2, 20, and $200 \mathrm{mM}$ concentrations. Gln, glutamine; NAG, acetyl glutamine; WST, water-soluble tetrazolium salt; M \pm S.D., mean \pm standard deviation.

7.5), $50 \mathrm{mM} \mathrm{NaCl}, 1 \% \mathrm{NP}-40,0.5 \%$ sodium deoxycholate, $0.1 \%$ SDS, protease inhibitor cocktail (Roche, Switzerland)) 로 $30 \mathrm{~min}$ 간 세포를 용해하였다. 용해된 세포는 $4^{\circ} \mathrm{C}$ 에서 12,000 $\mathrm{g}$ 으로 $30 \mathrm{~min}$ 간 원심분리하여 상등액을 회수한 후, SDS sample buffer (60 mM Tris (pH 6.8), 14.4 mM 2-mercaptoethanol, $25 \%$ glycerol, $2 \% \mathrm{SDS}, 0.1 \%$ bromophenol blue)를 첨가하고 $100^{\circ} \mathrm{C}$ 에서 $5 \mathrm{~min}$ 끓여 단백질을 denaturation 시킨 후 단백질을 $\mathrm{SDS}-\mathrm{PAGE}$ 로 분자량별로 분리하였다. 분리된 단백질은 $100 \mathrm{~V}$ 의 조건에서 $1 \mathrm{~h}$ 동안 nitrocellulose membrane (Whatman, UK) 으로 transfer 한 후, membrane을 $5 \%$ skim milk 용액에서 1 $\mathrm{h}$ 동안 교반하여 blocking 하였다. 그 후 membrane에 primary antibody 용액을 처리하여 $4^{\circ} \mathrm{C}$ 에서 $18 \mathrm{~h}$ 동안 교반한 후 $\mathrm{TBS} / \mathrm{T}$ (10 mM Tris-Cl (pH 7.5), $150 \mathrm{mM} \mathrm{NaCl}, 0.2 \%$ Tween 20)로 5 $\min$ 씩 3 회 세척하였다. 세척된 membrane에 화학적 형광을 낼 수 있는 horseradish peroxidase (HRP)가 결합되어 있는 secondary antibody 용액을 상온에서 $2 \mathrm{~h}$ 처리 후 다시 TBS/T로 $5 \mathrm{~min}$ 씩 3회 세척하였다. Secondary antibody가 처리된 membrane 은 super signal west pico solution (Pierce, USA)를 처리하고 실 험용 필름(Konica, Japan)에 감광을 유도한 후 감광된 필름을 자 동현상기(QX-130II, Konica)를 이용하여 현상하여 단백질 band 의 변화를 관찰하였다. Antibody는 $\beta$-actin, involucrin primary antibody (Sigma); p53, p21 primary antibody (Santa Cruz, USA); keratin 1 primary antibody (Covance, USA)를 사용하였 다.

\section{RNA 추출과 CDNA 제조}

시료가 처리된 세포에서의 RNA 추출은 phenol 성분이 첨가된 Trizol reagent (Invitrogen, USA)를 이용하여 시행하였다. 수확 한 세포가 들어있는 tube에 $1 \mathrm{~mL}$ Trizol reagent를 넣고 상온에서
$5 \mathrm{~min}$ 세포를 용해하였다. 여기에 $0.2 \mathrm{~mL}$ chloroform (Biopure, Canada)을 첨가하고 강하게 $15 \mathrm{~s}$ 흔들어 준 뒤 $3 \mathrm{~min}$ 상온에 방 치하고 $12,000 \mathrm{~g}, 4^{\circ} \mathrm{C}$ 의 조건에서 $20 \mathrm{~min}$ 원심분리를 실시하여 $\mathrm{RNA}$ 층을 분리하였다. 분리된 $\mathrm{RNA}$ 층에 $0.5 \mathrm{~mL}$ isopropanol (Biopure)을 첨가하여 상온에서 $10 \mathrm{~min}$ 방치 후, $12,000 \mathrm{~g}, 4^{\circ} \mathrm{C}$ 의 조건으로 $15 \mathrm{~min}$ 원심분리를 실시하여 $\mathrm{RNA}$ 를 침전시켰다. 침전된 $\mathrm{RNA}$ 는 $75 \%$ ethanol로 세척하고 상온에서 건조한 후 diethylpyrocarbonate (DEPC) water로 녹여 실험에 사용하였다. RNA의 순도는 Nanodrop (Nanodrop, USA)을 이용하여 측정된 $260 \mathrm{~nm} / 280 \mathrm{~nm}$ 의 ratio를 통해 확인하였으며, ratio 1.8 이상의 $\mathrm{RNA}$ 만을 실험에 사용하였다. $\mathrm{PCR}$ 실험에 사용하기 위한 $\mathrm{cDNA}$ 는 M-MLV reverse transcriptase (Enzynomics, Korea)을 사용 하여 제조하였다. $1 \mu \mathrm{g}$ RNA와 $0.5 \mathrm{ng}$ oligo dT18에 DEPC water 를 첨가한 $10 \mu \mathrm{L}$ 의 용액을 $70^{\circ} \mathrm{C}$ 에서 $10 \mathrm{~min}$ 처리하여 $\mathrm{RNA}$ 를 denaturation 시켰다. 여기에 buffer, $10 \mathrm{mM} \mathrm{dNTP,} 200 \mathrm{unit} / \mu \mathrm{L}$ reverse transcriptase를 첨가하여 $37^{\circ} \mathrm{C}$ 에서 $1 \mathrm{~h}$ 반응시켜 cDNA 를 제조하여 실험에 사용하였다.

\section{Quantitative real-time PCR}

$\mathrm{Gln}, \mathrm{NAG}$ 에 의해 세포 내에서 일어나는 유전자 발현 변화를 정 량적으로 확인하기 위하여 quantitative RT-PCR (qRT-PCR)을 실시하였으며, SYBR 염색 기법에 사용되는 EvaGreen dye를 적용 하여 결과를 확인하였다. qRT-PCR은 HOT FIREPol EvaGreen PCR Mix Plus (Solis BioDyne, Estonia), 1 pmole forward primer, 1 pmole reverse primer, $10 \mathrm{ng} \mathrm{cDNA}$ 를 혼합하여 반응 액을 제조 후 Linegene K (BioER, China)를 이용하여 진행하였 으며, 세부 과정은 다음과 같다. $94^{\circ} \mathrm{C}$ 에서 $5 \mathrm{~min}$ denaturation 시 킨 후 $94^{\circ} \mathrm{C}$ 에서 denaturation, $60^{\circ} \mathrm{C}$ 에서 annealing, $72{ }^{\circ} \mathrm{C}$ 에서 polymerization 과정을 각각 $30 \mathrm{~s}$ 수행하여 총 40 cycle 동안 반 

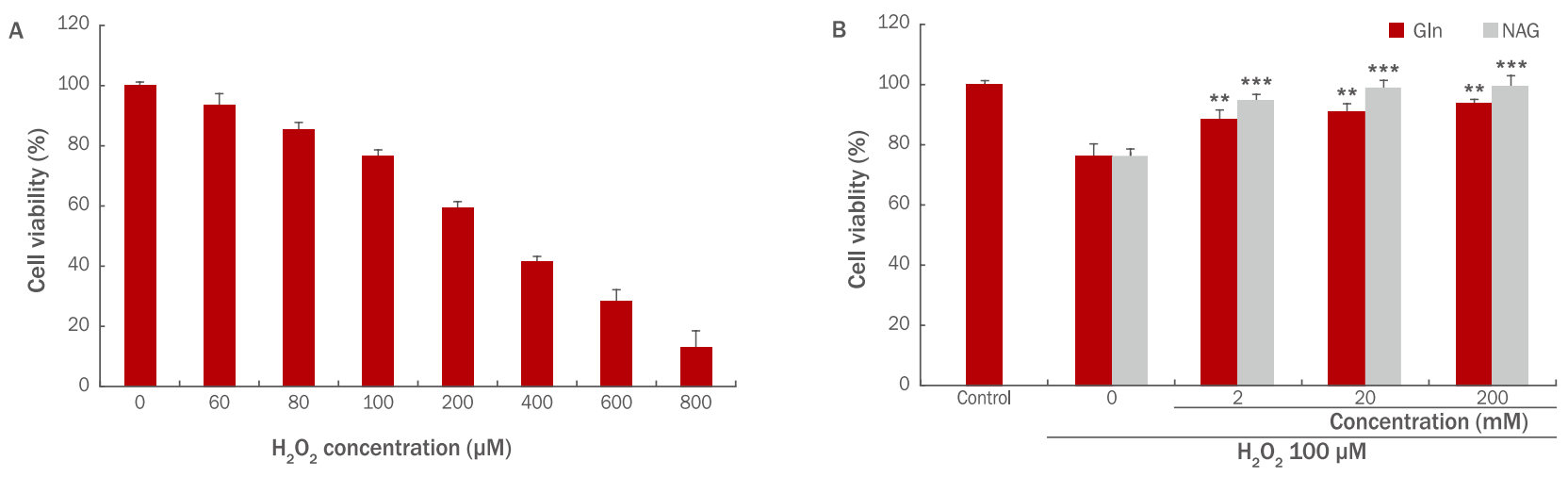

Figure 2. The effect of GIn and NAG on cell viability in $\mathrm{H}_{2} \mathrm{O}_{2}$-treated HaCaT.

(A) $\mathrm{HaCaT}$ cell viability was decreased with increasing $\mathrm{H}_{2} \mathrm{O}_{2}$ concentration $(60,80,100,200,400,600,800 \mu \mathrm{M})$. (B) The effect of Gln and NAG on cell viability in $100 \mathrm{MM} \mathrm{H}_{2} \mathrm{O}_{2}$-treated HaCaT was measured by the WST-1 assay. Cell viability by Gln and NAG was increased in a dose dependent manner in $\mathrm{H}_{2} \mathrm{O}_{2}$-treated HaCaT. The graph represents the $\mathrm{M} \pm \mathrm{S}$.D. of the relative cell viability in each sample from triplicate experiments. The student's $t$-test was conducted to determine statistical significance $\left({ }^{* *} p<0.01,{ }^{* * *} p<0.001\right)$. Gln, glutamine; NAG, acetyl glutamine; WST, water-soluble tetrazolium salt; M \pm S.D., mean \pm standard deviation.

복하여 실시하였다. PCR 결과의 검증은 각 결과별 melting curve 로 검증하였으며, 결과는 각 유전자의 threshold cycle $(\mathrm{Ct})$ 값을 $\beta-\mathrm{actin}$ 의 $\mathrm{Ct}$ 값으로 표준화한 후 $\mathrm{Ct}$ 값의 변화량을 비교하여 분석 하였다. Ct 값은 PCR 산물에 의해 발생하는 형광 값이 일정한 기준 값에 도달했을 때의 증폭 주기를 나타낸 것으로 대조군의 $\mathrm{Ct}$ 값과 의 비교를 통해 실험군의 유전자 발현량을 확인할 수 있다. 실험에 사용된 각 유전자의 primer는 Table 1 과 같다.

\section{Results and Discussion}

\section{1. 인간 각질형성세포에 대한 독성}

$\mathrm{HaCaT}$ 에 Gln과 NAG를 각각 $0.002,0.02,0.2,2,20,200$ $\mathrm{mM}$ 농도로 $24 \mathrm{~h}$ 처리하여 세포 독성을 확인한 결과, 두 시료 모두 독성이 없는 것으로 확인되었다. 특히 Gln $200 \mathrm{mM}$ 처리 시에는 $111 \%$, NAG $200 \mathrm{mM}$ 처리 시에는 $118 \%$ 로 NAG의 세포 생존율이 더 높았으며 다른 농도에서도 전반적으로 $\mathrm{NAG}$ 의 생존율이 더 높았 다(Figure 1).

\section{2. 인간 각질형성세포 보호효과}

본 시험에서는 $\mathrm{NAG}$ 의 $\mathrm{H}_{2} \mathrm{O}_{2}$ 에 대한 $\mathrm{HaCaT}$ 보호효과를 알아
보기위해 $\mathrm{H}_{2} \mathrm{O}_{2}$ 를 사용하여 산화적 스트레스를 유도하고 세포 생 존률 변화를 확인하였다. $\mathrm{HaCaT}$ 에 $\mathrm{H}_{2} \mathrm{O}_{2}$ 를 각 $60,80,100,200$, $400,600,800 \mu \mathrm{M}$ 로 처리할 경우 $100 \mu \mathrm{M}$ 의 농도에서 $76 \%$ 의 생 존율을 보였기 때문에 $\mathrm{HaCaT}$ 에서의 $\mathrm{H}_{2} \mathrm{O}_{2}$ 적용 농도는 $100 \mu \mathrm{M}$ 로 설정하였다(Figure 2A). Gln, NAG를 2, 20, $200 \mathrm{mM}$ 전처리 후 $\mathrm{H}_{2} \mathrm{O}_{2} 100 \mu \mathrm{M}$ 을 처리하여 세포 생존율 변화를 확인한 결과 $\mathrm{Gln}$ 과 NAG 모두 농도 의존적으로 세포 생존율을 회복시킴을 알 수 있 었다. Gln $2 \mathrm{mM}$ 은 88\%, $20 \mathrm{mM}$ 은 91\%, $200 \mathrm{mM}$ 은 93\%의 생존 율을 보였으며, NAG $2 \mathrm{mM}$ 은 94\%, $20 \mathrm{mM}$ 은 $98 \%, 200 \mathrm{mM}$ 은 $99 \%$ 의 생존율을 보였다. 이를 통해 Gln과 NAG 모두 $20 \mathrm{mM}$ 이상 의 농도에서는 생존율의 변화가 거의 없음을 알 수 있었고, NAG가 $\mathrm{H}_{2} \mathrm{O}_{2}$ 에 의해서 저하된 세포 생존율을 더욱 효과적으로 증가시킴을 알 수 있다(Figure 2B). 따라서 이후 실험에서는 Gln과 NAG 모두 $20 \mathrm{mM}$ 의 농도에서 효능을 확인하였다.

\section{3. 세포 노화 억제효과}

Gln과 NAG가 세포 노화에 미치는 영향을 확인하기 위하 여 SA- $\beta$-galactosidase assay를 실시하였다. HaCaT에 Gln, $\mathrm{NAG}$ 만을 $20 \mathrm{mM}$ 의 농도로 처리할 경우, 노화된 세포의 비율은 무처리군과 차이가 없었으므로 $\mathrm{Gln}, \mathrm{NAG}$ 은 세포 노화에 영향을 미치지 않음을 추측할 수 있다. $100 \mu \mathrm{M}$ 의 $\mathrm{H}_{2} \mathrm{O}_{2}$ 를 처리했을 경

Table 1. Lists of primers used in this study

\begin{tabular}{lll}
\hline Gene & Forward primer & Reverse primer \\
$\beta$-actin & GGATTCCTATGTGGGCGACGA & CGCTCGGTGAGGATCTTCATG \\
MMP1 & TCTGACGTTGATCCCAGAGAGCAG & CAGGGTGACACCAGTGACTGCAC \\
COL1A1 & AGGGCCAAGACGAAGACATC & AGATCACGTCATCGCACAACA \\
\hline
\end{tabular}

MMP1, matrix metallopeptidase 1; COL1A1, collagen, type I, alpha 1. 


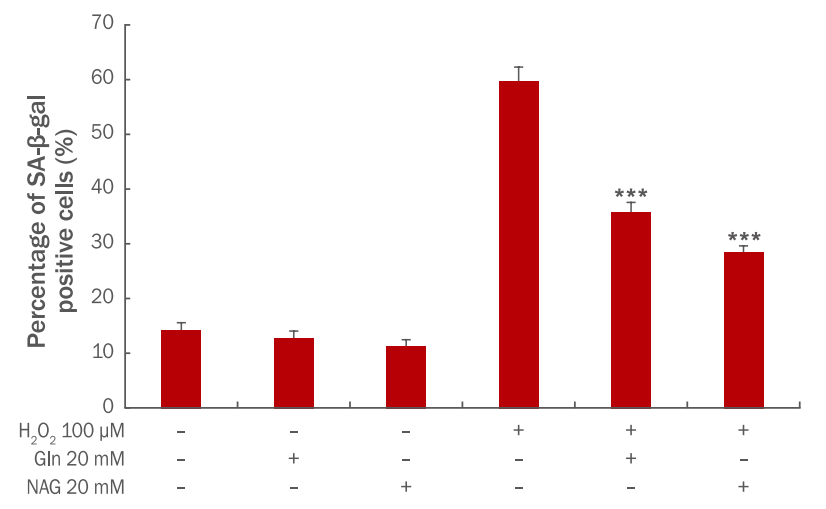

Figure 3. The effect of GIn and NAG on senescence in $\mathrm{H}_{2} \mathrm{O}_{2}$ induced HaCaT.

$\mathrm{H}_{2} \mathrm{O}_{2}$-induced HaCaT were treated with Gln 20 mM and NAG 20 $\mathrm{mM}$. And then cellular senescence level was measured by using a senescence associated $\beta$-galactosidase assay. The results are presented as $M \pm S$.D. of three independent experiments. The student's $t$-test was conducted to determine statistical significance $\left({ }^{* * *} p<0.001\right)$. Gln, glutamine; NAG, acetyl glutamine; M \pm S.D., mean \pm standard deviation.

A

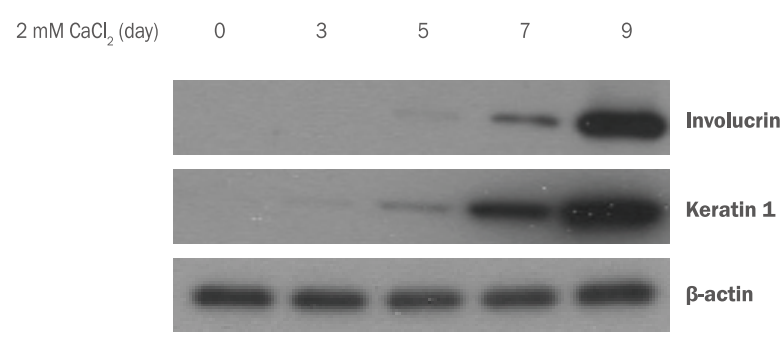

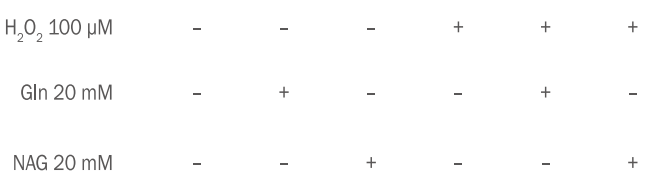

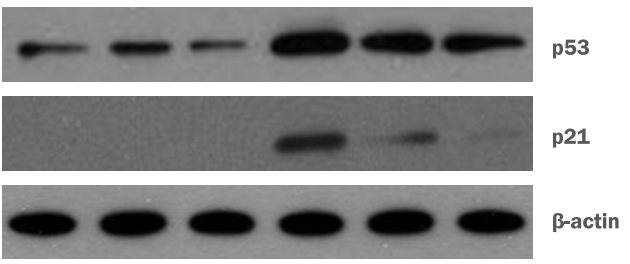

Figure 4. Inhibition of p53 accumulation by GIn and NAG in $\mathrm{H}_{2} \mathrm{O}_{2}-$ induced HaCaT.

Western blotting was performed to confirm the change of p53 activity by GIn and NAG treatment. P53 accumulation by 20 $\mathrm{mM}$ GIn and $20 \mathrm{mM}$ NAG In $100 \mathrm{\mu M} \mathrm{H}_{2} \mathrm{O}_{2}$-induced HaCaT was decreased. In p53 accumulation, 20 mM NAG treatment decreased more than $20 \mathrm{mM}$ Gln treatment. Gln, glutamine; NAG, acetyl glutamine; $\mathrm{M} \pm$ S.D., mean \pm standard deviation.

B
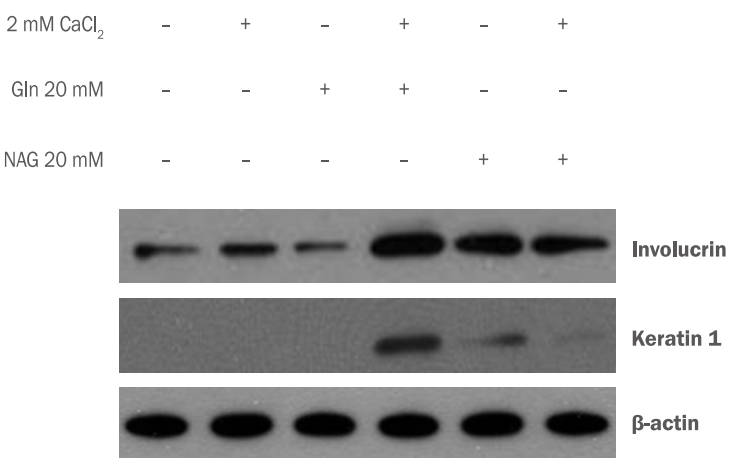

Figure 5. The effect of GIn and NAG on differentiation in HaCaT.

To investigate the effect of GIn and NAG on HaCaT differentiation, the changes of involucrin and keratin 1 were confirmed by Western blotting analysis. (A) The expressions of involucrin and keratin 1 were increased from 7 days after treatment with $2 \mathrm{mM}^{\mathrm{CaCl}}{ }_{2}$ to induce differentiation of HaCaT. (B) Both Gln and NAG showed increased the expression of involucrin and keratin 1 compared to CaCl $_{2}$ alone. NAG at $20 \mathrm{mM}$ increased expressions of keratin 1 and involucrin remarkably more than Gln. Gln, glutamine; NAG, acetyl glutamine.

우, 노화된 세포 비율이 $60 \%$ 로 증가하여 $\mathrm{H}_{2} \mathrm{O}_{2}$ 가 $\mathrm{HaCaT}$ 의 노화 를 촉진하는 것을 알 수 있었다. 노화된 세포 비율은 Gln $20 \mathrm{mM}$ 전처리 시 $36 \%$, NAG $20 \mathrm{mM}$ 전처리 시 $28 \%$ 로 감소하여 두 시 료 모두 세포 노화를 억제하였다(Figure 3). 그러나 NAG에서 더 높은 감소율을 보였기 때문에 NAG가 $\mathrm{H}_{2} \mathrm{O}_{2}$ 로 인한 세포 노화로 부터 $\mathrm{HaCaT}$ 를 더 효과적으로 보호함을 알 수 있다.

\section{4. $\mathrm{p} 53$ 활성 억제}

Gln과 NAG 처리에 의한 p53의 활성 변화를 확인하기 위하여 western blotting을 실시하였다. $\mathrm{HaCaT}$ 에 $100 \mu \mathrm{M} \mathrm{H} \mathrm{H}_{2}$ 만을 처
리하면 p53의 양이 무처리군에 비하여 급격하게 증가하지만, Gln $20 \mathrm{mM}$, NAG $20 \mathrm{mM}$ 을 각각 전처리 시 감소함을 확인하였다. $\mathrm{p} 21$ 의 경우 무처리군에서는 거의 발현이 되지 않으나 $\mathrm{H}_{2} \mathrm{O}_{2}$ 처리 시 급격하게 단백질양이 증가하고, Gln과 NAG 처리 시 감소함을 보였다. 특히, NAG $20 \mathrm{mM}$ 처리 시 무처리군과 유사한 수준으로 감소하여 NAG가 세포 노화를 억제함을 알 수 있다(Figure 4),

\section{5. 각질형성세포 분화 조절}

Gln과 NAG가 $\mathrm{HaCaT}$ 분화에 영향을 주는지 확인하기 위해 $\mathrm{HaCaT}$ 에 Gln, NAG를 처리하고 involucrin과 keratin1의 단백 

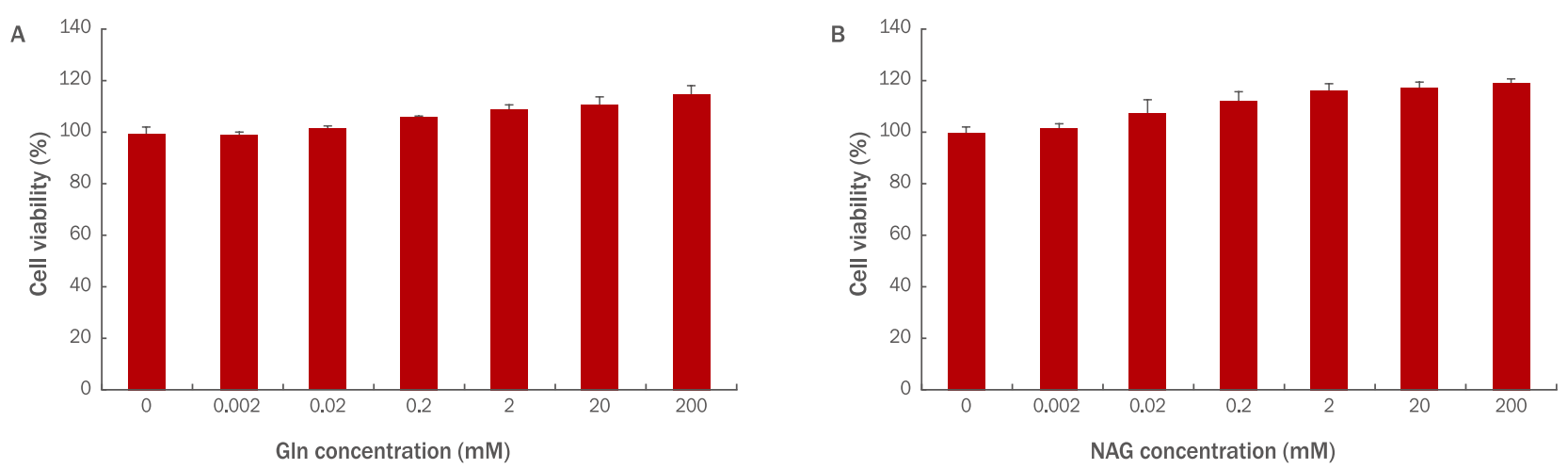

Figure 6. Cytotoxicity of GIn and NAG on HDFs.

Cell viability of Gln (A) and NAG (B) on HDFs $\left(3 \times 10^{3}\right)$ was measured by the WST-1 assay. (A) Gln was non-toxic to HDFs at the $0.002,0.02$, $0.2,2,20$, and $200 \mathrm{mM}$ concentrations. (B) NAG was non-toxic to HDFs at the 0.002, 0.02, 0.2, 2, 20, and 200 mM concentrations. Gln,

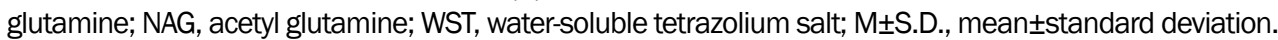
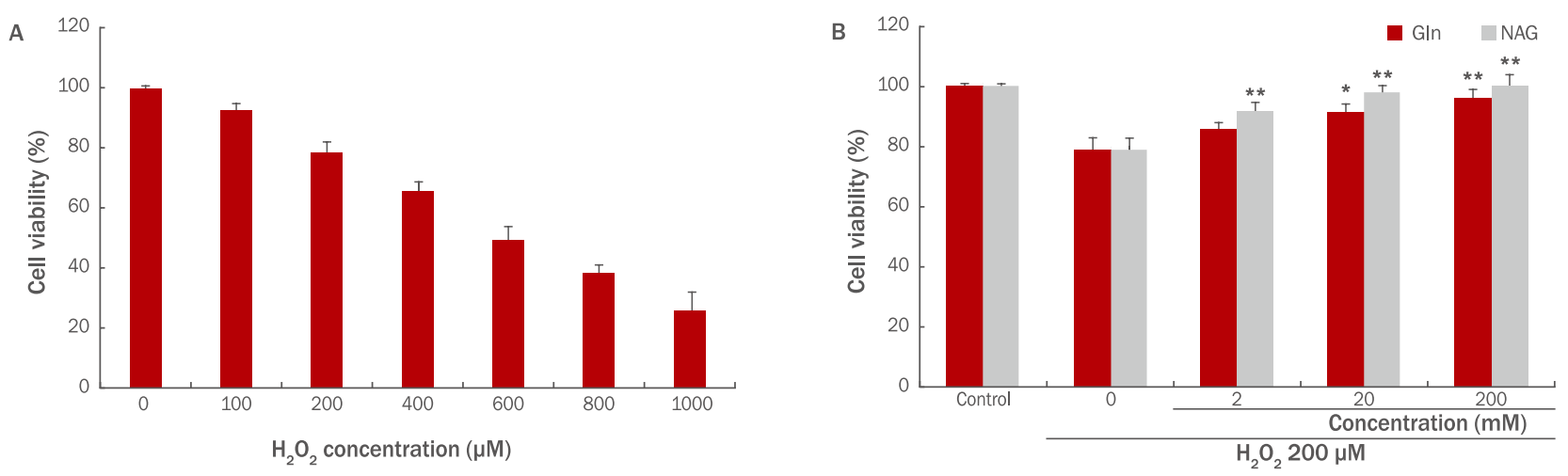

Figure 7. The effect of GIn and NAG on cell viability in $\mathrm{H}_{2} \mathrm{O}_{2}$-treated HDFs.

(A) Cell viability was decreased with increasing $\mathrm{H}_{2} \mathrm{O}_{2}$ concentration $(100,200,400,600,800,1000 \mu M)$. (B) The effect of Gln and NAG on cell viability in $200 \mu \mathrm{M} \mathrm{H}_{2} \mathrm{O}_{2}$-treated HDFs was measured by the WST-1 assay. Cell viability by Gln and NAG was increased in a dose dependent manner in $200 \mu \mathrm{M} \mathrm{H}_{2} \mathrm{O}_{2}$-treated HDFs. The graph represents the $\mathrm{M} \pm \mathrm{S}$.D. of the relative cell viability in each sample from triplicate experiments. The student's $t$-test was conducted to determine statistical significance $\left({ }^{*} p<0.05,{ }^{* *} p<0.01\right)$. Gln, glutamine; NAG, acetyl glutamine; WST, water-soluble tetrazolium salt; $\mathrm{M} \pm$ S.D., mean \pm standard deviation.

질 변화를 western blotting analysis로 확인하였다. $2 \mathrm{mM} \mathrm{CaCl}_{2}$ 를 처리하여 $\mathrm{HaCaT}$ 의 분화를 유도한 결과 7일부터 involucrin과 keratin 1 의 양이 증가하기 시작하고 9 일에는 발현이 급격하게 증 가하여 분화가 되었음을 알 수 있었다(Figure $5 \mathrm{~A}$ ). Gln과 NAG가 분화 조절에 미치는 영향을 확인하기 위하여 7일 조건에서 실험을 진행하였다. $\mathrm{HaCaT}$ 에 $2 \mathrm{mM} \mathrm{CaCl}_{2}$ 와 Gln $20 \mathrm{mM}$, NAG $20 \mathrm{mM}$ 을 처리 후 단백질 변화를 관찰한 결과 $\mathrm{Gln}, \mathrm{NAG}$ 모두 $\mathrm{CaCl}_{2}$ 단독 처리군에 비하여 involucrin과 keratin 1 의 발현이 증가함을 확인 하였다. 특히, NAG $20 \mathrm{mM}$ 처리군에서는 Gln $20 \mathrm{mM}$ 처리군보 다 keratin 1 과 involucrin의 발현이 현저하게 증가함을 확인하여 $\mathrm{NAG}$ 가 각질형성세포의 분화를 촉진하는 효능이 더 우수함을 확인 하였다(Figure $5 \mathrm{~B}$ ). 이러한 결과는 NAG가 각질형성세포의 분화
초기와 후기의 신호전달계 활성화에 영향을 준 것으로 추측할 수 있다.

\section{6. 인간 진피섬유아세포에 대한 독성}

$\mathrm{HDFs}$ 에 농도별로 Gln, NAG을 처리하여 세포 독성을 확인한 결과 $\mathrm{HaCaT}$ 과 마찬가지로 두 시료 모두 독성이 없었으며(Figure $6 \mathrm{~A}, 6 \mathrm{~B}), \mathrm{NAG}$ 처리에 의한 생존율이 더 높게 나타났다(Figure $6 B)$.

\section{7. 인간 진피섬유아세포 보호효과}

$\mathrm{HDFs}$ 에 $\mathrm{H}_{2} \mathrm{O}_{2}$ 를 처리했을 때 $\mathrm{H}_{2} \mathrm{O}_{2}$ 의 농도가 높아질수록 세포 생존율이 감소하였다. $200 \mu \mathrm{M}$ 의 농도에서 약 $80 \%$ 의 생존율을 보 

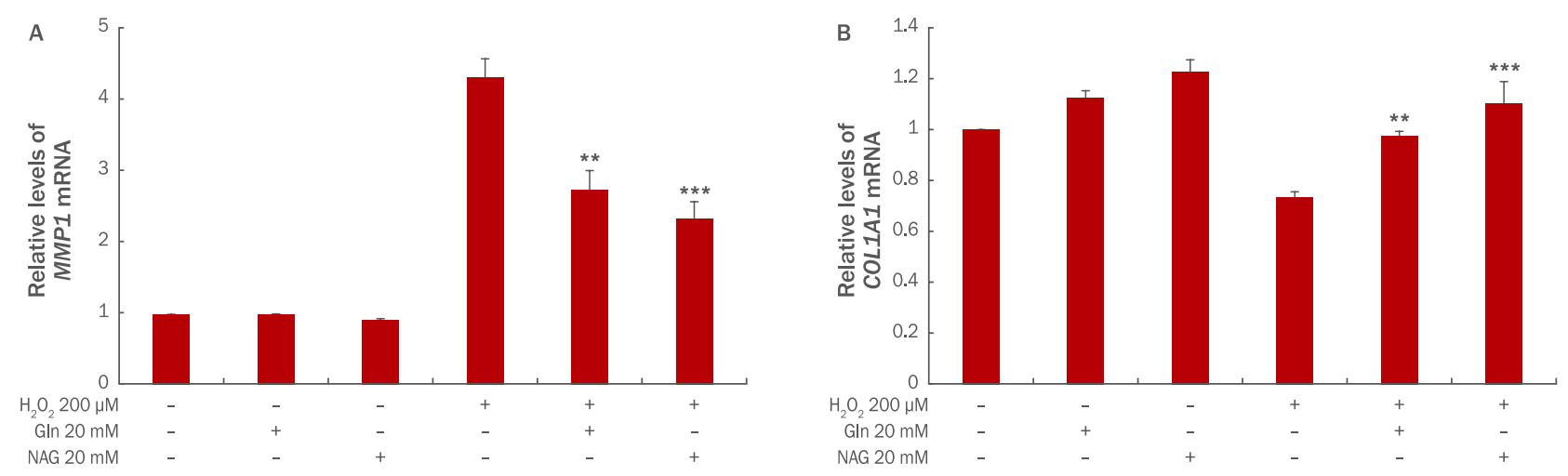

Figure 8. The effect of GIn and NAG on MMP1 mRNA (A) and COL1A1 mRNA (B) expression in $\mathrm{H}_{2} \mathrm{O}_{2}$-treated HDFs.

(A) The expression of MMP1 mRNA was increased 4.3 folds at $200 \mu \mathrm{M} \mathrm{H}_{2} \mathrm{O}_{2}$-treated HDFs, and was decreased 2.7 folds in the case of Gln $20 \mathrm{mM}$ treatment and 2.3 folds in the case of NAC $20 \mathrm{mM}$ treatment. (B) The expression of COL1A1 mRNA was decreased 0.7 folds at $200 \mu \mathrm{M} \mathrm{H}_{2} \mathrm{O}_{2}$-treated HDFs, and was increased 0.9 folds in the case of Gln $20 \mathrm{mM}$ treatment and 1 folds in the case of NAC $20 \mathrm{mM}$ treatment. The results are presented as $\mathrm{M} \pm \mathrm{S}$.D. of three independent experiments. The student's $t$-test was conducted to determine statistical significance $\left({ }^{* *} p<0.01,{ }^{* * *} p<0.001\right)$. MMP1, matrix metallopeptidase 1; COL1A1, collagen, type I, alpha 1; Gln, glutamine; NAG, acetyl glutamine; $\mathrm{M} \pm \mathrm{S}$.D., mean \pm standard deviation.

였고 그 이상의 농도에서는 생존율이 $70 \%$ 미만으로 나타나 $\mathrm{HDFs}$ 에 대한 $\mathrm{H}_{2} \mathrm{O}_{2}$ 처리 농도는 $200 \mu \mathrm{M}$ 로 설정하였다(Figure 7A). $\mathrm{Gln}$ 과 NAG의 $\mathrm{H}_{2} \mathrm{O}_{2}$ 에 대한 $\mathrm{HDFs}$ 보호효과를 알아보기 위해 $\mathrm{HDFs}$ 에 $200 \mu \mathrm{M}$ 의 $\mathrm{H}_{2} \mathrm{O}_{2}$ 를 처리하고 $\mathrm{Gln}, \mathrm{NAG}$ 를 각각 2, 20, $200 \mathrm{mM}$ 의 농도로 전 처리하여 생존율의 변화를 확인하였다. Gln $2 \mathrm{mM}$ 은 $85 \%, 20 \mathrm{mM}$ 은 $91 \%, 200 \mathrm{mM}$ 은 $95 \%$ 의 생존율을 보였 으며, NAG $2 \mathrm{mM}$ 은 91\%, $20 \mathrm{mM}$ 은 98\%, $200 \mathrm{mM}$ 은 99\%의 생 존율을 보였다(Figure 7B). 이를 통해 HDFs에서도 역시 NAG가 $\mathrm{H}_{2} \mathrm{O}_{2}$ 에 의해서 저하된 세포 생존율을 더욱 효과적으로 증가시킴 을 알 수 있다.

\section{MMP1 유전자 발현억제 및 $C O L 1 A 1$ 유전자 발현촉진}

$\mathrm{HDFs}$ 에 $\mathrm{H}_{2} \mathrm{O}_{2}$ 에 의한 산화적 스트레스가 발생하면 콜라겐 분 해 효소인 MMP1의 발현은 증가하고, 콜라겐의 생성은 감소한 다. 그로인해 진피층의 탄력이 감소되고, 주름이 생성된다(Kim \& Yoon, 2013). Gln과 NAG가 MMP1 mRNA 및 COL1A1 mRNA 발현에 미치는 영향을 확인하기 위해 $\mathrm{qRT}-\mathrm{PCR}$ 을 실시하였다. 그 결과, $M M P 1 \mathrm{mRNA}$ 의 발현은 $\mathrm{H}_{2} \mathrm{O}_{2} 200 \mu \mathrm{M}$ 처리 시 무처리 군에 비해 4.3배 증가하였으며, Gln $20 \mathrm{mM}$ 전처리 시 2.7배, $\mathrm{NAG} 20 \mathrm{mM}$ 전처리 시 2.3 배로 발현이 감소하여 NAG가 $M M P 1$ $\mathrm{mRNA}$ 발현을 감소시켰다(Figure $8 \mathrm{~A}$ ). $\mathrm{HDFs}$ 에 $\mathrm{H}_{2} \mathrm{O}_{2}$ 를 처리하 면 피부 콜라겐 유전자인 $C O L 1 A 1$ 의 발현은 0.7 배 감소하였다. 그러나 $\mathrm{Gln}$ 과 $\mathrm{NAG}$ 를 각각 $20 \mathrm{mM}$ 전처리하면 COL1A1의 발현 이 증가하였으며, NAG 전처리 시 발현이 더 증가함을 확인하였다 (Figure 8B). 이러한 결과를 통해 NAG는 COL1A1 유전자의 발 현을 촉진하고, $M M P 1$ 유전자의 발현을 저해함으로써 피부 탄력 과 주름을 개선시키는 효력이 있음을 추측할 수 있다.

\section{Conclusion}

본 연구에서는 산화적 스트레스가 유도된 인간 피부세포에서 아세틸글루타민의 노화억제 및 각질형성세포 분화조절로 인한 피 부장벽을 강화시키는 보습제로서의 효능을 세포효력시험을 통해 검증하였다.

첫째, 아세틸글루타민은 피부세포의 노화를 억제한다. 아세틸 글루타민은 $\mathrm{H}_{2} \mathrm{O}_{2}$ 에 의해 증가하였던 노화된 세포의 비율과 $\mathrm{p} 53$ 과 $\mathrm{p} 21$ 의 발현을 감소시켜 $\mathrm{HaCaT}$ 에서 $\mathrm{H}_{2} \mathrm{O}_{2}$ 에 의해 유도되는 노화 를 효과적으로 억제하였다. 또한 $\mathrm{HDFs}$ 에서 $M M P 1$ 유전자의 발 현을 감소시켰고, type I collagen의 유전자인 COL1A1 유전자의 발현은 증가시켜 $\mathrm{H}_{2} \mathrm{O}_{2}$ 에 의한 산화적 스트레스로부터 진피층의 결합조직이 손상되는 것을 효과적으로 억제했다.

둘째, 아세틸글루타민은 피부장벽 기능을 강화한다. 아세틸글 루타민은 대표적인 분화 표지인자인 keratin 1 과 involucrin의 발 현을 증가시켜 각질형성세포의 분화를 촉진하는 효력이 글루타민 보다 더 우수하였다. 이러한 결과는 아세틸글루타민이 각질형성 세포의 분화 초기와 후기의 신호전달계 활성화에 영향을 준 것으 로 추측할 수 있다.

이상과 같은 결과는 아세틸글루타민이 효과적인 노화 억제 물 질로서 항노화와 주름 개선, 보습제로서의 피부장벽 기능 강화, 피부상태 개선 효능을 확인한 것으로 화장품 원료로써의 충분한 가치를 보여주는 것이라 할 수 있다.

This work is a part of Hyun Hee Jang's Ph.D. thesis at the Konkuk University, Seoul, Korea. 


\section{References}

Agostini F, Biolo G. Effect of physical activity on glutamine metabolism. Current Opinion in Clinical Nutrition \& Metabolic Care, 13: 58-64, 2010.

Brasse-Lagnel C, Lavoinne A, Husson A. Control of mammalian gene expression by amino acids, especially glutamine. The FEBS Journal, 276: 1823-1844, 2009.

Choi BH, Hur EM, Lee JH, Jun DJ, Kim KT. Protein kinase Cסmediated proteasomal degradation of MAP kinase phosphatase-1 contributes to glutamate-induced neuronal cell death. Journal of Cell Science, 119: 1329-1340, 2005.

Choi EH, Oh YS. Skin barrier abnormality in atopic dermatitis. Journal of Asthma, Allergy and Clinical Immunology, 28: 175181, 2008.

Chang MY, Kim JJ, Lee CK. Moisturizers in cosmetics: classification of moisturizers by action mechanism. The Journal of Skin Barrier Research, 9: 18-26, 2007.

Jeong HS, Yun CJ, Lee JS. The expression of human beta defensins by thermal injury. Journal of Korean Burn Society, 15: 39-44, 2012.

Joo KM, Han JY, Son ED, Nam GW, Jeong HJ, Lim KM, Cho JC. Study on the relationship between skin dryness and amino acids in stratum corneum. Journal of the Society of Cosmetic Scientists of Korea, 38: 75-82, 2012.

Kwon YB, Choi DK, Sohn KC, Jeon EK, Nam MS, Lee JH, Kim $\mathrm{CD}$. Effects of colostrum on keratinocyte differentiation and wound healing. Korean Journal of Investigative Dermatology, 14: 45-50, 2007.

Kim SM, Park KB, Bae YJ, Shin HJ, Yeo YC, Lee MK, Lim SB, Lim LS, Choi SY, Han SK, et al. Cosmetic dermatology: principles and practice. Jungdammedia, Seoul, pp19-24, 2004. (Baumann L, 2002).

Kim YR, Cho SY, Seo DB, Kim SH, Lee SJ, Cho Y. Effects of oral intake of gromwell water fraction on ceramides content and the development of atopic dermatitis in NC/Nga mice. Korean Journal of Food Science and Technology, 41: 547551, 2009.

Kim Y, Han SM, Cho Y. The dietary effect of royal jelly supplementation on epidermal levels of filaggrin and free amino acids during menopause in rats. Journal of the Korean
Society of Food Science and Nutrition, 42: 389-396, 2013 a.

Kim H, Shin JU, Lee KH. Atopic dermatitis and skin barrier dysfunction. Allergy Asthma \& Respiratory Diseases, 1: 2028, 2013b.

Kim YJ, Yoon Y. Regulation of Col1A1 and MMP1 expression by taurine, major component of oyster, in human dermal fibroblasts. Asian Journal of Beauty and Cosmetology, 11: 393-397, 2013.

Lee SS, Kim SY, Im M, Lee Y, Lee JH, Seo YJ. The influence of physiologic lipid containing moisturizer on the normal skin barrier. Korean Journal of Dermatology, 49: 339-344, 2011.

Newsholme P, Lima MM, Procopio J, Pithon-Curi TC, Doi SQ, Bazotte RB, Curi R. Glutamine and glutamate as vital metabolites. Brazilian Journal of Medical and Biological Research, 36: 153-163, 2003.

Park BD, Youm JK, Ahn SK, Lee SH. The function and clinical effectiveness of moisturizer as an adjunctive therapy. The Journal of Skin Barrier Research, 5: 37-45, 2003.

Park CS. The skin barrier and moisturizer. The Journal of Skin Barrier Research, 9: 11-17, 2007.

Seo SJ. Genetic factors of atopic dermatitis. The Journal of Skin Barrier Research, 14: 20-27, 2012.

Singleton KD, Beckey VE, Wischmeyer PE. Glutamine prevents activation of NF-kB and stress kinase pathways, attenuates inflammatory cytokine release, and prevents acute respiratory distress syndrome (ARDS) following sepsis. Shock, 24: 583-589, 2005.

Wischmeyer PE. Glutamine: role in critical illness and ongoing clinical trials. Current Opinion in Gastroenterology, 24: 190197, 2008.

Yoon Y, Bae S, An S, Choe YB, Ahn KJ, An IS. Effects of ultraviolet radiation on the skin and skin cell signaling pathways. Asian Journal of Beauty and Cosmetology, 11: 417-426, 2013.

Yoon Y. Gene expression profiling in protection mechanism of silibinin against damage to human dermal fibroblasts caused by UVB. Asian Journal of Beauty and Cosmetology, 11: 93102, 2013.

Zhang F, Wang X, Wang W, Li N, Li J. Glutamine reduces TNF- $\alpha$ by enhancing glutathione synthesis in lipopolysaccharidestimulated alveolar epithelial cells of rats. Inflammation, 31: 344-350, 2008. 


\section{국문초록}

\section{아세틸글루타민의 피부세포 노화억제 및 피부장벽 기능 강화효과}

장현희

경복대학교 예술학부, 경기도 남양주시, 한국

목적: 본 연구는 화장품 원료로서 아세틸글루타민의 피부세포 노화억제 및 피부장벽 기능 강화효과를 세포 효력시험을 통해 검 증하는데 목적이 있다. 방법: 아세틸글루타민의 세포효력을 검증하기 위하여 세포생존율, SA- $\beta$-galactosidase assay, Western blotting, quantitative real-time PCR을 실시하였다. 결과: 아세틸글루타민은 인간 각질형성세포주 (HaCaT)와 인간 진피섬유아세 포(human dermal fibroblast, $\mathrm{HDF}$ )에 대한 독성이 없었으며, 아세틸글루타민 $20 \mathrm{mM}$ 처리 시 $100,200 \mu \mathrm{M}$ 의 $\mathrm{H}_{2} \mathrm{O}_{2}$ 에 의해서 감소 된 각각의 세포 생존율이 증가하였다. $\mathrm{HaCaT}$ 에 $\mathrm{H}_{2} \mathrm{O}_{2}$ 를 처리하여 유도된 세포노화 실험에서 $20 \mathrm{mM}$ 농도의 아세틸글루타민이 글 루타민보다 노화된 세포를 더 많이 감소시켰다. 아세틸글루타민 $20 \mathrm{mM}$ 처리 시 글루타민보다 keratin 1 과 involucrin의 발현이 현 저하게 증가하여 아세틸글루타민이 각질형성세포의 분화를 촉진하는 효력이 더 우수함을 확인했다. 아세틸글루타민은 또한 $\mathrm{H}_{2} \mathrm{O}_{2}$ 에 의해서 활성화되는 대표적 전사인자인 $\mathrm{p} 53$ 이 핵 내에 축적되는 것을 저해하고, $\mathrm{p} 53$ 에 의해서 발현되는 $\mathrm{p} 21$ 의 양도 감소시켰 다. $\mathrm{H}_{2} \mathrm{O}_{2}$ 처리 시 발현이 증가하는 $M M P 1$ 유전자는 아세틸글루타민 처리 시 발현이 감소하였고, 반면 $\mathrm{H}_{2} \mathrm{O}_{2}$ 에 의해 발현이 감소한 $C O L 1 A 1$ 유전자는 아세틸글루타민에 의해서 발현이 증가하였다. 이러한 결과는 아세틸글루타민이 $\mathrm{H}_{2} \mathrm{O}_{2}$ 에 의해 유도된 세포노화를 효과적으로 억제함을 보여주는 것이다. 결론: 이상과 같이 아세틸글루타민의 피부세포 노화억제 및 피부장벽 기능 강화 효과를 검 증하였고, 화장품 원료로서 충분한 가치가 있다고 사료된다.

핵심어: 아세틸글루타민, 피부장벽, 피부노화, 각질형성세포, 진피섬유아세포

\section{참고문헌}

권유빈, 최대경, 손경철, 전은경, 남명수, 이증훈, 김창덕. 각질형성 세포 분화 및 상처치유에 대한 초유의 효과. 대한피부 연구학회지, 14: 45-50, 2007.

김석민, 박기범, 배영재, 신현주, 여운철, 이미경, 임성빈, 임이석, 최성우, 한승경 등. 코스메틱 피부과학: 원리 및 임상. 정담미디어, 서울, pp19-24, 2004. (Baumann L, 2002).

김영란, 조시영, 서대방. 김성한, 이상준, 조윤희. 자초 추출물 극성 성분의 피부 보습 증진 및 아토피 피부염 호전 효과.

한국식품과학회지, 41: 547-551, 2009.

김영주, 윤영민. 굴의 주요성분인 Taurine이 Collagen과 MMP 발현 조절에 미치는 영향. 아시안뷰티화장품학술지, 11 :

393-397, 2013.

김예지, 한상미, 조윤희. 폐경기 노화 유도 전후의 로얄제리 식이공급이 백서 표피의 필라그린과 유리아미노산 함량 및 관

련 대사 효소의 단백질 발현 변화에 미치는 영향. 한국식품영양과학회지, 42: 389-396, $2013 \mathrm{a}$.

김현정, 신정우, 이광훈. 아토피피부염과 피부 장벽 이상. 알레르기 천식 호흡기질환, $1: 20-28,2013 \mathrm{~b}$.

박병덕, 염종경, 안성구, 이승헌. Adjunctive therapy로서 보습제의 기능 및 효과. 한국피부장벽학회지, 5: 37-45,

2003.

박장서. 피부장벽과 보습제. 한국피부장벽학회지, 9: 11-17, 2007.

서성준. Genetic Factors of Atopic Dermatitis. 한국피부장벽학회지, 14: 20-27, 2012.

윤영민. UVB에 대한 Silibinin의 세포보호 기전에 작용하는 유전자 발현 프로파일링. 아시안뷰티화장품학술지, 11: 93-

$102,2013$.

윤영민, 배승희, 안성관, 최용범, 안규중, 안인숙. 자외선(Utraviolet)이 피부 및 피부세포 내 신호전달체계에 미치는 영향. 
아시안뷰티화장품학술지, 11: 417-426, 2013.

이상신, 김수연, 임명, 이영, 이증훈, 서영준. 생리적지질을 함유한 보습제가 정상피부에 미치는 영향. 대한피부과학회지, 49: 339-344, 2011.

장민열, 김진준, 이천구. 화장품과 보습제(Moisturizers): 작용기전에 따른 보습제의 종류. 한국피부장벽학회지, 9: 18$26,2007$.

정효선, 윤천재, 이정숙. 열 손상에서의 디펜신의 발현. 대한화상학회지, 15: 39-44, 2012.

주경미, 한지연, 손의동, 남개원, 정혜진, 임경민, 조준철. 아미노산 동시분석을 통한 피부보습능과 각질 중 아미노산 함량 과의 상관관계 연구. 대한화장품학회지, 38: 75-82, 2012.

최응호, 오윤석. 아토피 피부염에서 피부장벽 이상. 천식 및 알레르기, 28: 175-181, 2008. 


\section{中文摘要}

\section{乙酰谷氨酰胺抑制皮肤细胞老化以及增强皮肤屏障功能}

張現喜

京福大学美容艺术系，京畿道南杨州市，韩国

目的：通过细胞活力测试验证乙酰谷氨酰胺（acetyl glutamine，NAG）对皮肤细胞衰老抑制和皮肤屏障功能 作为化妆品原料的作用。方法: 为测量NAG的细胞功效, 进行细胞生存率测定, SA- $\beta$-半乳糖苷酶测定, 蛋白质 印迹和定量实时PCR。结果：NAG对人角质形成细胞系（HaCaT）和人皮肤成纤维细胞（HDF）无毒。被100， $200 \mu \mathrm{M} \mathrm{H}_{2} \mathrm{O}_{2}$ 处理而减少的细胞生存率, 利用 $20 \mathrm{mM}$ 的NAG处理时, 其细胞生存率逐渐增加。发现 $20 \mathrm{mM} \mathrm{NAG}$ 减少 $\mathrm{H}_{2} \mathrm{O}_{2}$ 诱导的HaCaT中的衰老细胞远远超过谷氨酰胺（glutamine, Gln）。20 mM的NAG增加 keratin 1 和 involucrin的表达显着高于Gln。这表明NAG比GIn具有更好的促进表皮角质形成细胞分化的功效。此外，NAG 还减少了p53（一种同源四聚体转录因子）的核积累，同时减少由p53表达的p21的量。NAG降低由 $\mathrm{H}_{2} \mathrm{O}_{2}$ 诱导增 加的基质金属肽酶1（matrix metallopeptidase 1，MMP1） mRNA的表达水平，反而增加了由 $\mathrm{H}_{2} \mathrm{O}_{2}$ 诱导降低的 collagen, type I, alpha 1 (COL1A1)表达水平。结果表明NAG有效控制 $\mathrm{H}_{2} \mathrm{O}_{2}$ 触发的衰老细胞。结论: 如上所述, 已显示NAG抑制皮肤细胞衰老并增强皮肤屏障功能，并且被认为具有作为化妆品原料充分具有价值。

关键词: 乙酰谷氨酰胺, 皮肤屏障, 皮肤老化, 角质形成细胞, 真皮纤维细胞 
